\title{
COVID 19: Eğitimde Yeni Arayışlar
}

\author{
Metin Işık ${ }^{1^{*}}$, İsa Bahat ${ }^{2}$ \\ 1,2Kırşehir Ahi Evran Üniversitesi, Kaman Uygulamalı Bilimler Yüksekokulu, Yönetim Bilişim Sistemleri Bölümü, Kırşehir \\ ORCID: M. Işık (0000-0002-7431-4091), I. Bahat (0000-0002-5600-2449)
}

\begin{abstract}
Özet
Küreselleşme ile bilginin hızlı yayılması ve yaşanan teknolojik gelişmeler, bireysel ve toplumsal yaşantıyı farklı boyutlarda etkilemektedir. Dünyada ve ülkemizde yaşanan Covid-19 (Korona virüs) salgını bireysel ve sosyal hayatı önemli ölçüde sınırlandırmaktadır. Korona virüs, diğer alanlarda olduğu gibi eğitim alanında da birtakım değişikliklere ve olumsuzluklara neden olmuştur. Covid-19 salgını, başta ekonomi olmak üzere eğitim sistemleri ile toplumsal ve bireysel hayatı derinden etkilemektedir. Salgının hem yaygınlığı hem de etkilerinin derinliği göz önünde bulundurulduğunda, yaşanan salgının insanlığın yakın tarihte karşılaştığı en büyük kriz olduğu söylenebilir. Salgının ne zaman sona ereceği ile ilgili farklı kestirimler olmasına rağmen bittikten sonra da etkilerinin başta eğitim olmak üzere tüm yaşam alanlarında devam edeceği öngörülmektedir. Covid-19 salgını öncesinde ve sonrasında öğrenme ortamlarında dijitalleşmeye yönelik pek çok gelişme yaşanmıştır. Bu gelişmeler ile eğitim öğretim sürecinde yaşanan zorunlu değişimler öğrenci, öğretmen ve bütün eğitim paydaşlarını etkilemiştir. Bu süreçte başta merkezi hükümet olmak üzere tüm karar vericiler yaşanacak olumsuzlukların önüne geçmek, salgının etkisini ve yayılımını azaltmak için birçok önlem almıştır. Eğitim alanında ise alınan önlemlerden birisi de yüz yüze eğitime ara vermek ve mümkün olan şekliyle tüm eğitim süreçlerini uzaktan eğitim şeklinde gerçekleştirmek olmuştur. Bu çalışma eğitimdeki pandemi risklerine karşı yapılabilecekler konusunda oldukça önem arz etmektedir. Çalışmada, doküman inceleme yöntemi ile pandemi sürecinde Türkiye'de Milli Eğitim Bakanlığı́nın uzaktan eğitime yönelik stratejileri incelenmiştir. Çok yakın gelecekte sürekli öğrenme bağlamında uzaktan eğitim, Korona virüs gibi zorunlu durumlar dışında da yüz yüze öğrenme gibi asıl eğitim platformu olacağı öngörülebilir.
\end{abstract}

Anahtar kelimeler: Covid 19, uzaktan eğitim, eğitimde yeni arayışlar.

\section{The Coronavirus: New Quests in Education}

\begin{abstract}
The rapid spread of information and technological developments with globalization affect individual and social life in different dimensions. The Covid-19 (Corona virus) epidemic in the world and in our country significantly limits individual and social life. The corona virus has caused some changes and negativities in the field of education, as in other fields. The Covid-19 epidemic deeply affects education systems, especially the economy, and social and individual life. Considering both the prevalence and the depth of its effects, it can be said that the epidemic is the biggest crisis humanity has faced in recent history. Although there are different predictions and scientific opinions about when the epidemic will end, it is predicted that the effects of the epidemic will continue in all areas of life, especially education. There have been many developments regarding digitalization in learning environments before and after the Covid-19 outbreak. With these developments, the obligatory changes experienced in the education process affected students, teachers and all education stakeholders. In this process, all decision-makers, especially the central government, have taken many measures to prevent adversities and reduce the impact and spread of the epidemic. In the field of education, one of the measures taken was to suspend face-to-face education and to realize all education processes as distance education as possible. This study is very important about what can be done against the risk of pandemic that the education. In this study, the strategies of Ministry of Education in Turkey for distance education in the pandemic process are analyzed with document scanning methods. In the very near future, it can be predicted that it will be the main educational platform such as face-to-face learning in the context of continuous learning, except for compulsory situations such as distance education and Corona virus.
\end{abstract}

Key words: Covid 19, distance learning, new perspectives in education.

\section{GíRiş}

Eğitim, bireyleri her alanda yaşama hazırlayan, toplumların ve ulusların sosyo-kültürel, ekonomik ve teknolo-

*Yazışma Adresi / Address for Correspondence: M. Işık, Email: metinziya09@hotmail.com

Geliş Tarihi / Received Date: 20.09.2020

Kabul Tarihi / Accepted Date: 19.02.2021

Doi: 10.26701/uad.797635 jik birçok alanda kalkınma ve gelişmesini destekleyen önemli süreç olarak kabul edilir (Özgenel, Işık ve Bahat, 2019). Eğitim ile öğrenme, hayat boyu sürerek zaman ve mekandan bağımsız bireyde kalıcı değişiklikler oluşturmaktadır (Şişman, 2010). Bireyin yaşadığı her türlü değişim, toplumsal düzeyde de farklı boyutlarda yansımaktadır. Toplumsal değişmelerin temelinde bireylerin gelişmelerine yön veren ve onları güdüleyen kendi ihtiyaçları en önemli eğitim aracı olarak görülebilir. Eğitim her bireyin fizyolojik, güvenlik, sevgi, saygı ve kendini 
gerçekleştirme ihtiyaçlarını şekillendiren en önemli araçların başında gelmektedir (Tekke, 2019). Özellikle eğitim hizmetlerinde bireyi tanımada kişinin hem kendi potansiyelinin farkında olması hem de başkalarıyla olumlu ve farklı tecrübelerin elde edilmesi etkili eğitime büyük katkı sağlayacaktır. Cao, Jiang, Oh, Li, Liao ve Chen (2013) fiziksel ihtiyaçları bu hiyerarşi içinde en temel olarak kabul etmektedir. Ancak virüsün hızla tüm dünyaya yayılması insanın sahip olması gereken önceliklerini değiştirerek yenilerini öne çıkarmıştır.

1 Aralık 2019'da Çin'de ortaya çıkarak tüm dünyada sağllk, ekonomi, sosyal hayat ve eğitim üzerinde oldukça önemli değişimlere neden olan Coronavirüs salgını, Dünya Sağlık Örgütü tarafından 11 Mart 2020'de küresel bir pandemi olarak ilan edilmiştir (Can, 2020: 12). Küresel olarak COVID-19 salgını nedeniyle, 17 Nisan 2020 itibarıla dünyada 191 ülkede okullar kapatıldı ve 1.724.657.870 öğrenci bu süreçten etkilendi. Virüsün küresel bağlamda ülkeleri etkilemesi sonucunda ülkeler vatandaşlarının en temel ihtiyacı olarak da sağlığını korumak için karantina, sıkıyönetim gibi farklı önlemler alınmasına sebep olmuştur. Salgının etkilerinin azaltılması için bütün ülkelerde herkesin evde kalmasına yönelik uygulamalar diğer tüm yaklaşımlara göre daha etkili olduğundan zorunlu olarak benimsenmiştir. Korona virüs ile mücadele edebilmek için öncelikle insan sağllğını koruma yanında ekonomik önlemlerin alınması da uluslararası bağlamda en önemli ve öncelikli konu olarak görülmüştür. Nitekim OECD, mevcut ve gelecekteki salgınlara karşı bağışılklık geliştirmek için G20 ülkelerinin liderlerine insan sağlığının korunması, uluslararası iş birliğinin gerekliliği ve üretimin sürekliliğinin sağlanması yönünde farklı uluslararası kuruluşların açıklamalarına benzer (OECD, 2020) açıklamada bulunmuştur. Çünkü salgın sona erdiğinde üretimden eğitime bütün alanlarda sürekliliğin sağlanması beklenmektedir.

Dünya genelinde bütün eğitim kademelerinde bir milyardan fazla öğrenci, yüz yüze eğitimden dolayısıyla okuldan uzak kaldığı salgın döneminde ülkeler eğitimde oluşan zorunlu boşluğu farklı eğitim uygulamalarıyla doldurarak sürecin eğitim üzerindeki olumsuz etkilerini azaltmaya çalışmışlardır (Özer, 2020). Tüm dünyada karantina sebebiyle beklenmedik bir şekilde yüz yüze eğitim yerine evde dijital platformlar aracılığı ile eğitim sürdürülmeye ve desteklenmeye başlanmıştır. Dünyada pek çok ülke kitlesel bir uzaktan eğitime hazırlıksız yakalanırken mevcut farklı sosyo-ekonomik gruplar arasındaki olanak ve dijital okuryazarlık farkları uzaktan eğitimin gelecekteki sonuçlarının tartışılmasına sebep olmaktadır (Özer, 2020). Türkiye sahip olduğu Milli Eğitim Bakanlığı Eğitim Bilişim Ağı (EBA) ve EBA TV altyapısı ile uzaktan eğitime yönelik donanımsal yeterlilikleri açısından diğer ülkelerle karşılaştırıldığında birçoğuna göre daha hazır görülmektedir. Erktin'e (2020) göre Korona virüs salgın döneminde uzaktan eğitimde odaklanılan teknolojiler kadar eğitimin içeriğine de önem verilerek karma eğitim modellerinin kullanılması gerekmektedir. $\mathrm{Bu}$ dönem, eğitim teknolojilerinin kullanımı açısından önemli bir fırsatlar sunmakla birlikte her eğitim düzeyinde uygulamada öğrencilerin yeterlilikleri ve hazırbulunuşlukları değerlendirilerek farklı yöntem ve teknikler kullanılmalıdır. Örneğin ilk ve ortaöğretim düzeylerinde uygulanan uzaktan veya yüz yüze eğitimde özellikle teknoloji okuryazarlığına ilişkin yeterlikleri belirlenerek gereksinimlerinin karşılanmasına önem verilmelidir. Çünkü salgın sürecinden kaynaklanan olumsuzluklar öğrencilerin geleceklerine olumsuz yansıyacaktır. Salgın sürecinde toplumun en çok dikkatini çeken ve sıklıkla kullanmaya başladığı eğitim kavramları eğitim teknolojileri, bilgisayar ve internet teknolojileri, uzaktan eğitim, hayat boyu öğrenme, e öğrenme, dijital öğrenme olarak görülmektedir.

Korona virüs ile ortaya çıkan koşullar kısa bir sürede dünya çapında yenilikçi çözümler aramayı ve eğitimde değişimi zorunlu kılmıştır. Geleneksel eğitime olan bağlılığa rağmen insanların eğitim anlayışlarını büyük ölçüde değiştirmiştir. Geçmişte her değişiklik bireylerde bir ölçüde rahatsızlığa neden olurken salgın döneminde eğitime yönelik üretilen yeni çözümlere ve yaşanan değişimlere karşı insanların daha anlayışılı olmalarına sebep olmuştur. Çünkü toplumların geçmişi incelendiğinde siyasi, kültürel, ekonomik ya da teknolojik gelişmelerin toplumları ve eğitimi büyük ölçüde etkilediği görülmektedir (Şişman, 2010). Korona virüs salgını sonrasında ülkelerin neredeyse tamamı zorunlu olarak çevrimiçi eğitim uygulamasını hayata geçirerek yüz yüze eğitimi askıya almıştır. Bu da artık çevrimiçi eğitimin tek çare haline geldiğini göstermektedir. Ülkemiz de diğer ülkeler gibi eğitimin sürdürülebilirliği ve öğrenenlerin boşluğa düşmemesi amacıyla olanaklara göre çevrimiçi eğitim sistemlerine dönüş yapmışlardır (Telli Yamamoto ve Altun, 2020). Türkiye'de eğitim alanında bilgisayarın okullara girmeye başlaması ile günümüze kadar teknolojinin bütün alanlarda kullanımının toplumsal değişmeyi hızlandırdığ 1 ifade edilebilir (Kırmızıgül, 2020).

FATİH (Fırsatları Artırma Teknolojiyi İyileştirme Hareketi) Projesi, 2012 yılında pilot okullarda uygulanmasına başlanmıştır. Milli Eğitim Bakanlığı, teknolojik olanaklardan yararlanarak eğitimi Türkiye'nin her yerine götürmeyi ve eğitimde fırsat eşitliğini sağlamayı hedeflemektedir. Eğitimde yeni teknolojilerin kullanılması ve yaygınlaştırılmasına yönelik olarak bütün okulların internet erişimine kavuşması, bilişim teknolojileri sınıflarının yaygınlaştırılması, bir bilgisayara düşen öğrenci sayısı göstergesinin hızla iyileştirilmesi, öğretmenlerin taşınır bilgisayar edinmeleri için sağlanan teşviklerin sürdürülmesi, bilgi çağında eğitim gereklerinin yerine getirilmesine yönelik kampanyaların yürütülmesi olumlu gelişmeler olarak değerlendirilir (Telli Yamamato, 2012).

Toplumların hızlı değişimlerine sebep olan tarihte ya- 
şanmıș sıra dışı olaylar gibi günümüzde yaşanan Korona virüs salgını ile tüm dünyada ve ülkemizde bütün boyutlarıyla yaşanmaktadır. Uzaktan eğitim sürecinde evlerdeki olanak ve öğrenme farklılıkları daha belirginleşirken bilgi iletişim teknolojilerine erişimde ve kullanım becerisinde yaşanan eşitsizlik öğrenmeyi daha zor ulaşılan bir süreç haline getirmiştir. Öğrencinin akademik gelişimini ve başarısını etkileyen anne babanın eğitim durumu, evdeki kitap sayısı gibi pek çok sosyo-ekonomik etken uzaktan eğitim sürecinde daha da artmıştır (Aktaş, 2020). Ancak herkesin kabul ettiği gibi okullar, eğitim yuvası olmalarının yanı sıra çocukların ve gençlerin sosyalleştiği ve ileriki yaşlardaki sosyal hayata da hazırlandıkları ortamlardır. Geleceğin çalışanları ve liderleri olacak bugünün öğrencilerinin sosyal ilişkilerinde ve iş hayatlarında başarılı olabilmeleri için sosyal, duygusal ve akademik her türlü desteğe ihtiyaçları vardır (Gündüz Öğüdücü, 2020). Öğrencilerin uzaktan eğitim sebebiyle sosyalleşememeleri ve arkadaşlık ilişkisi kuramamalarına yönelik psikolojik desteğe en az yüz yüze eğitimin boşluğunu doldurmaya yönelik beklenen akademik destek kadar ihtiyaçları vardır.

\section{KORONA VIRÜS (COVID-19) VE UZAKTAN EĞіTiM}

Uzaktan eğitim, Amerika'da mektup ile 1700'lerde başlamış, yazılı ders materyallerinin posta ile gönderilmesi, radyo-televizyon ve sinema ile çoklu ortam çağına girmesi, bilgisayar ve internet teknolojileri ile gelişen (Ergüney, 2015) bir süreçtir. İnternet aracılığıyla eğitim süreci, e-öğrenme biçiminde gerçekleşmektedir. Öğrencilerin, okul dışında, uzakta eş ya da ayrı zamanlı internet üzerinden iletişim kurarak bilgi aldıkları eğitim sistemidir (Gökdaş ve Kayri, 2005). Türkiye'de uzaktan eğitim 4 döneme ayrılmaktadır (Bozkurt, 2017).

- Dönem: Kavramsal (1923-1955)

- Dönem: Mektupla (1956-1975)

- Dönem: Radyo-Televizyon (1976-1995)

- Dönem: İnternet-Web (1996-...) (https://tr.wikipedia.org).

Türkiye'de uzaktan eğitim hizmetlerinin sunumu açısından en kapsamlı yasal düzenlemelerden olan "Üniversitelerarası İletişim ve Bilgi Teknolojilerine Dayalı Uzaktan Yükseköğretim Yönetmeliği” (1999) ile derslerin ve programların belirlenmesi ve kredilendirilmesi, istemci ve sunucu üniversitelerin belirlenmesi, öğrenci kabulü, kayıt, sınav ve ders geçme yöntemleri, malî hükümler ve yurtdışındaki kurum ve kuruluşlardan alınacak dersler ile ilgili standartlar ortaya konulmuştur. Bu yönetmelik, günümüzde üniversitelerin uzaktan eğitim merkezi açabilmelerinin yasal dayanağını oluşturmaktadır. Üniversiteler son yıllarda, bu yönetmelik kapsamında uzaktan eğitim merkezleri bünyesinde uzaktan eğitim programları ve etkinlikleri yürütmektedirler (Telli Yamamato ve
Can, 2013: 194).

Türkiye'de uzaktan eğitim yükseköğretimde Anadolu Üniversitesi (1982), Atatürk Üniversitesi ve İstanbul Üniversite'lerinde (2010) kurulan Açıköğretim Fakülteleri ile farklı üniversitelerde kurulan uzaktan eğitim merkezleri aracılığı ile gelişmiştir.

Uzaktan eğitim, farklı yerlerde bulunan öğretmen ve öğrencilerin iletişimiyle onlara bireysel ve iş birliğine uygun çalışma alanı sağlamaktadır (Altıparmak, Kurt ve Kapıdere, 2011). Uzaktan eğitimde öğretmen, öğrenci ve iletişim metodu (Moore, 1973) olan üç ana elemandan herhangi birindeki yetersizlik, sistemi bir bütün olarak başarısızlığa götürebilir. Mekan ve zamandan bağımsız olarak eğitim yapma kolaylığı uzaktan eğitimin en önemli amacıdır. Literatürde, üniversitelerde sayıları günden güne artan uzaktan eğitim programlarının etkinliği üzerine yapılmış olan çeşitli araştırmalar göze çarpmaktadır (Simonson, 2007; Pina, 2008). Uzaktan eğitim ya da çevrimiçi (online) eğitim öğrenci ve öğretmenlerin fiziki bir derslikten bağımsız olarak internet bağlantısı yoluyla bir araya gelerek uygulanan ders sistemidir. Hastalık gibi özel sebeplere derslerden geri kalmak gibi bir durum olmadan istenilen zamanda tekrar yapılabilir. Sınıf ortamında farklı öğrenme düzeyindeki öğrenciler arasında oluşan stres ve baskıyı ortadan kaldırır ve öğrenme sürecini hızlandırır (Cantekin, 2020).

Geçen yıllar içerisinde uzaktan eğitim, internet teknolojilerinin de sağladığı avantajlar ile önce bilgisayar ortamında verilmeye başlanmış, daha sonra bağlantı hızlarının artması ve mobil cihazların gelişmesi sayesinde mobil eğitime doğru değişmiştir (Telli Yamamoto ve Altun, 2020). Günümüzde ise Korona virüs salgını süresince tercih edilen en önemli öğrenme aracı eğitim teknolojisidir. Salgın sonucunda eğitim öğretim süreciyle ilgili olarak alınan kararlar, dijitalleşen eğitim ve uzaktan eğitim sürecinde öğrenciler ile ailelerini de etkilemiştir. Uzaktan eğitim ile öğrencilerin eğitimlerine evlerinde aktif devam etmeleri için ailelerinin de uzaktan eğitime katılımları sağlanmıştır. Ancak yaşanan sürece hazırlıksız yakalanılması uzaktan eğitim ortamlarında eğitim-öğretimin istenilen düzeyde gerçekleştirilmesini engellediği düşünülmektedir.

Dünya genelinde salgın süresince okulların kapanmasından dolayı Birleşmiş Milletler (BM) verilerine göre yaklaşı olarak 770 milyon kişi etkilenmiştir (BM, 2019). Dünyayı etkisi altına alan Korona virüs salgını, 2 milyarın üzerinde öğrenciye eğitim veren 63 milyon eğitimcinin zorlu bir sınav vermesine neden olmuştur. Eğitimciler bu süreçte, hem yeni nesil teknolojiye ve çevrimiçi eğitime uyum sağlarken hem de öğrencilerin motivasyonunu yükseltmek için uğraşmaktadırlar (Mocu, 2020). Şehirlerde hızlı nüfus artışı, küresel ölçekte hareketliliğinin hızlanması sebebiyle Korona virüs benzeri salgınların farklı düzeylerde her on yılda bir tekrarlanacağı öngörülmektedir. Bu ise önümüzdeki yıllarda "evde eğitim”in 
(home schooling) ve etkileşimli sanal/ çevrimiçi eğitimin çok fazla yaygınlaşacağını göstermektedir.

Günümüzde bilgi ve iletişim teknolojilerinin hızlı gelişimi diğer alanlarda olduğu gibi eğitim öğretimin dijitalleşmesini de hızlandırmaktadır. Ancak öngörülen bu durumlara yönelik bugün yapılması gereken en önemli şey öğretmenlerin dijital platformlar ile farklı öğrenme yöntem tekniklerin kullanımı konusunda hazırlıklı olmasının sağlanmasıdır. Çağdaș eğitimde kalitenin sağlanması ve amaçlara ulaşılması için eğitimcilerin yeterliklerinin yükseltilmesi gerekmektedir (Işık ve Çetin, 2019). Toplumlarda farklı alanlarda yaşanan gelişmelerle oluşan gereksinimleri karşılamaları beklenen öğretmenler, meslek bilgileri yönünden üst seviyede yetişmiş olarak kabul edilir (Yılman, 2006). Korona virüs salgını öncesinde ve sonrasında dijital dünyada ve öğrenme ortamlarında meydana gelen değişimler neticesinde eğitim öğretim süreci ve uygulamalarında farklı değişimler başta eğitimcileri etkilemiştir. Üstelik süreçte öğrencilerin öğrenme eksikliklerinin belirlenmesi ve telafi edilmesi, öğrencilere duygusal yönden destek sağlanması eğitimcilerin becerilerine ve motivasyonlarına bağlıdır (Karip, 2020).

Korona virüs salgınının eğitim sektörüne belki de en önemli etkilerinden biri okulların kapatılmasına yol açmasıdır. Okul kapanması öğrenme kaybına, artan okul bırakmaya ve yüksek eşitsizliğe yol açacaktır ve açmıştır. Sonuç olarak bunların insan sermayesi birikiminde, kalkınma beklentisinde ve refah seviyesinde uzun süreli zararı olacağı açıtır (World Bank Report, 2020). Eğitim asla uzun süreli durdurulamayacağı için geçici veya süreli çözüm yollarıyla eğitim aksatılmadan devam etmektedir (Kahraman, 2020). Ancak uzaktan eğitim ile ilgili salgın sürecinde yapılan araştırmalar yaşanan eksiklikleri göstermiştir. Uzaktan eğitimde içerik, materyal geliştirme ve ölçme değerlendirme uzaktan önemli sorunlar (Bozkurt, 2020; Özer ve Suna, 2020; Shisley, 2020 akt. Yıldırım, 2020) ve ölçme-değerlendirmede eksiklikler bulunmaktadır (Can, 2020).

Uzaktan eğitimle birlikte yaşanan firsat eşitsizliğinin daha da derinleştiği, okullar arasındaki imkân ve öğrenme farklılıkları gibi evler arasındaki imkân ve öğrenme farklılıkları daha da etkili hale geldiği görülmektedir. Dolayısıyla farklı sosyo-ekonomik koşullardaki bireylerin bilgi iletişim teknolojilerine (BİT) erişiminde ve bunları kullanımda yaşadığı eşitsizlik günümüz salgın şartlarında daha da belirginleşmiştir. Türkiye'de evlerde masaüstü bilgisayar $\%$ 17,6; taşınabilir bilgisayar \% 37,9; tablet \% 26,7; cep telefonu ise \% 98,7 oranında bulunmaktadır. Bilgisayar ya da tablet ile hiçbir şekilde internet erişimi bulunmayan öğrencilerin evlerinde yaşadıkları öğrenme ortamı birbirinden çok farklı özellikleri içermektedir. Ayrıca annelerinin telefonuna öğretmenleri tarafından Whatsapp üzerinden gönderilen ödevlerini tek bir telefon ile takip etmeye çalışmışlardır (Aktaş, 2020).
Günümüzde uzaktan öğrenme yerini e öğrenme ya da dijital öğrenmeye bırakmıştır. Türkiye'nin güncel gerçekliğinde eğitimde dijitalleşmede çok önemli dört unsur vardır (Arkan, 2020):

- Teknolojik altyapı,

- Eğitimcilerin sanal eğitim becerilerinin geliştirilip kapasitelerinin artırılması,

- Etkili sanal eğitim içeriği üretilmesi ve

- Çevrimiçi/sanal eğitimin etkili ölçme değerlendirme sistemlerinin üretilmesi.

Sanal eğitimde başarının en önemli öğesi insan kaynağ eğitimciler ve yöneticilerdir. Okulların kapalı kaldığı salgın sürecinde yönetimlerin eğitimcilerle ve eğitimcilerin kendi arasında iletişim ve etkileşimin sürekliliğini sağlamaya yönelik arayışlarda olduğu görülmektedir. Örgün eğitim başladığında da salgın sürecinde iletişim kurulan eğitimcilerden özveri beklenecektir. Kurumsallık ve paylaşımın kriz zamanlarında da devam etmesi birlikteliğin inandırıcı bir şekilde sürekliliğini sağlayacaktır (Karip, 2020). Okul yöneticilerinin bu süreçte eğitimciler ile iletişimi eğitim öğretimin niteliğine etkisini de bilerek etkin sürdürmesi gerekmektedir.

Eğitimcilerin ciddi bir şekilde desteklenmeye ve liderliğe ihtiyaçları vardır. Bu ihtiyaç üç noktada kendisini göstermektedir (Çetinkaya Aydın, 2020):

- İlgili eğitim teknolojilerinin kullanımı,

- Sanal eğitim sürecinin yönetimi; a) ders öncesi, b) ders süresi ve c) ders sonrası

- Sanal eğitim içeriği hazırlamada; Yüz yüze eğitimden farklı olarak eğitim lideri olarak etkinlikleri planlaması, geri bildirim vermesi ve yol göstermesi çok daha önemlidir.

Teknolojik gelişmeler toplumsal yaşamın her alanında yaşanan değişim sonucunda eğitim sisteminden teknolojiyi kullanabilen bireyler yetiştirilmesini beklemektedir. Eğitim sistemi de aynı işlevi öğretmenlerden beklemektedir. Bu beklenti teknoloji kullanımını öğretme ve öğretim etkinliklerinde kullanmayı kapsamaktadır (Akpınar, 2003: 80). Okullarda öğretmenlerin yeni teknolojiye ilişkin bilgi ve beceriler kazanması gerekmektedir. Çünkü yetiştirecekleri bireyleri "bilgi toplumuna" hazırlayan öğretmenlerin, bilgi toplumunun teknoloji destekli okul kültürünün oluşmasını desteklemeleri gerekmektedir (Leh, 1998). Öğretmenler bilgi teknolojilerinden bir araç olarak sınıf dışı eğitsel ve idari işler ile öğretim etkinliği yapmak için faydalanırlar. Bilgisayar ve bilgisayara bağlı yeni bilgi teknolojilerinin okullarda eğitsel ve yönetimsel işlerde kullanılması bilgi teknolojilerinin öğretmenler tarafından benimsenmesi ve uygulanmasına bağlıdır.

Öğretmenlerin sanal eğitim sürecinde karşılaştıkları güçlükleri, öğrencilerine ve eğitim-öğretime yönelik ya- 
şadıkları kaygıları uzaktan eğitim yöntem ve teknolojilerini kullanabilmeleri hafifletmektedir. Bu süreç sadece öğretmenler için değil, kullandıkları teknoloji, araç ve yöntemler ile ilgili bilgi ve becerileri görmeyi de sağlamaktadır. Bu anlamda, uzaktan öğretme-öğrenme teknoloji, araç ve yöntemlerinin gerçekten sadece onlara bağımlı kalınan bir durumda, nerede ne kadar işe yaradığını veya yetersiz kaldığını ayrıca öğretmenlerin yeterliklerini test etme imkânı sunmuștur (Çetinkaya Aydın, 2020). Ancak tespit edilen eksikliklerin uzaktan eğitim süreci içerisinde giderilebilmesi de teknoloji kullanımını gerektirmektedir.

Sanal eğitim, "sürekli öğretmen gelişimi" için büyük bir olanak sunmaktadır. Eğitimciler ihtiyaçları olduğu için etkili sanal hizmet içi eğitimlere ilgi duyacaktır. Eğitim sistemi içerisinde ihtiyaç duyulan alanları tespit edebilmek gerekir. Türk Milli Eğitim Sisteminin bunu bir firsata çevirebilmesi çok önemlidir (Altunel, 2020). Ersoy’a (2018) göre eğitim ve öğretimin en önemli unsuru olan öğretmenler, maddi ve manevi tüm yeterlilikleri sergileyebilmelidir. Ancak eğitim ortamlarında yaşanan olumsuzluklar uzun süre öğrencileri etkilenme derecesine bağlı olarak onları etkilemekte ve bireylerde güvensizlik, motivasyon düşüklüğü, özgüven eksikliği gibi olumsuzluklara sebep olmaktadır (Akmansoy, 2012). Okul yöneticileri ve öğretmenler, olumlu söylemlerle öğrencilerin içinde bulundukları olumsuz ve karmaşık ortamdan kurtarmalarını sağlayabilir (Bülbül, 2008). Öğretmenler yeterli teknolojik becerilere sahip olsa ve tüm öğrencilerle iletişim kurabilse bile uzaktan eğitim bazı yaş grupları, sınıf seviyeleri, dersler ve öğrenciler için yetersiz kalabilmektedir. Çünkü uzaktan eğitimde kullanılacak pedagojik yöntem ve stratejiler sınıf ortamında kullanılanlardan daha farklı olmak durumundadır. Öğrencilerin katılımını ve motivasyonunu sağlamak, öğrenmeyi takip etmek, öğrencilere uzaktan destek olmak için öğretmenlerin farklı yöntemler kullanması ve daha fazla çaba harcaması gerekir (Çetinkaya Aydın, 2020).

E-öğrenme çoklu ortam, etkileşimli medya, hiperlink, zengin medya ortamı gibi yapılar içerisinde elektronik olarak sunulan öğrenme biçimidir. Uzaktan öğrenme eş ve yarı zamanlı olarak gerçekleşebilir ve farklı uygulamalarla zenginleştirilebilir. Türkiye'de bir dönem televizyon aracıllğı ile gerçekleşen bilgilendirme de bir tür asenkron öğrenme olarak değerlendirilebilir. Buradaki önemli konu hazır bulunmayan öğrenci ve öğretim elemanlarının bu yeni duruma çok hızlı uyum sağlamasının beklenmesidir. Ancak uzaktan eğitimin avantaj ve dezavantajları bulunmaktadır (Telli Yamamoto, Demiray ve Kesim, 2011). Kırık (2014)'a göre uzaktan eğitim, zaman ve mekân sınırlarını ortadan kaldırarak eğitim-öğretimin sürekliliğini sağlamaktadır. Sınırlı fiziksel koşullar sebebiyle uzaktan eğitim uygulamalarına yönelim kaçınılmaz bir zorunluluk haline gelmiştir. Uzaktan eğitimin avantajları ise şu şekilde sıralanabilir (Keleş, 2020):
- Farklı öğrenme tekniklerinin kullanımı,

- Eş zamanlı daha fazla kişi ve daha fazla veriye erişim sağlar.

- Coğrafi engelleri ortadan kaldırır.

- Herkese uygun öğrenme yöntemi ve düșük maliyet sağlar.

- Zaman esnekliği ile her zaman istenen miktarda eğitim alınabilir.

- Öğrencilerde daha etkili eğitim ortamları sunarak performans artışı sağlar.

- Çevre dostu olarak e-öğrenme/uzaktan eğitim kağıt vb. malzeme kullanımını azaltır.

- Dezavantajlı öğrencilerin yaşadığı sorunlar, çevrimiçi eğitimde azalır ve bu sistem önemli kolaylıklar sağlar (E-öğrenme platformunun erişilebilir olması).

- Eğitimin ve öğrenme yönetim sistemleri (LMS- Learning Management System) ile öğretmen ve öğrencilerin tüm işlemleri takip edilebilir ve raporlanabilir.

Farklı sosyo-ekonomik yapıya sahip ailelerin çocukları arasında belirgin akademik başarı farklarının Korona virüs salgını nedeniyle özellikle okulların kapatılması ve uzaktan eğitim ile daha da artacağından endișe edilmektedir. Ayrıca yapılan bilimsel araștırmalar da yaz dönemlerinde yaşanan öğrenme kayıplarının ailelerin sosyo-ekonomik seviyelerine göre farklılık gösterdiği ve özellikle sosyo-ekonomik düzeyi düşük ailelerin çocuklarının süreçten daha olumsuz etkilendiği düşünülmektedir. Dolayısıyla önlemler alınmadığı takdirde salgın ile yaşananlar da büyük öğrenme kayıplarına yol açacak ve mevcut farklar daha da derinleșerek toplumsal maliyetin artmasına yol açacaktır (Özer, 2020).

Okulda eğitime ara verilmesinin tüm öğrenciler üzerinde etkisi aynı olmayacaktır. Öğrencilerin uzaktan öğrenmelerini ve öğrendiklerini varsaymak, uzaktan öğrenmede kendi başına öğrenme yeterliği sınırlı ya da erişim sorunu olan öğrenciler için kalıcı kayıplara neden olabilir. Uzaktan öğrenme sonucunda öğrencilerin gelişimine ilişkin bir ölçme ve değerlendirme yapılması not vermenin ötesinde bir işleve sahiptir (Karip, 2020). Bu yüzden okullarda örgün/yüz yüze eğitim başladığında öğrencilerin öğrenme kaybını belirlemek ve gidermek gerekir. Ölçme değerlendirme ile gereken telafiyi yapmamak özellikle ihtiyacı olan öğrenciler için çok büyük olumsuzlara yol açabilir (Burgess ve Sievertsen, 2020). Keleş (2020) de uzaktan eğitimin olumsuzluklarını şöyle sıralamaktadır:

- Herkesin kendi eğitimini yönetebilme disiplininin olmaması: Uzaktan eğitim yöntemlerinin en önemli avantajlarından olan kişinin kendi eğitim hızını kendisinin belirleyebilmesi, eğitim istenildiği yerde duraklatılabilir ve istenildiği kadar tekrar edilebilir olması gibi bazı uzaktan öğrenme yöntemleri yeteri kadar öğrenme isteği ve disiplini olmayan öğrencile- 
re olumsuz bir özgürlük sunar.

- Kaliteli ve iyi bir uzaktan öğrenme/e öğrenme sistemi geliştirmenin zor olması: Uzaktan öğrenme platformlarının hızlı çalışması, verilerin düzenli ve yapısal olması, eğitim gören ve eğitim verenlerin denetlenebilir olması, eğitimlere ait istatistiklerin olması özelliklerinin gerçekleşebilmesi zor ve maliyetlidir.

- Teknik yetersizliklerin eğitimi aksatması: Çevrimiçi eğitimlerde internet bağlantısı problemi gibi problemler ile internet bağlantısı dışındaki diğer teknik problemler eğitim aksatabilir.

- Güvenlik: uzaktan eğitim platformlarında özellikle resmi sertifika veren uzaktan öğrenme platformları güvenlik için sistemin açık kaynak olması ve periyodik bakım, güncelleme, yedekleme, barındırmasının yapılması önemlidir.

UNESCO (2020), Coronavirüs salgını nedeniyle eğitim sistemlerinin uzaktan eğitimde yaygın olarak kullandıkları bazı stratejilerin herkes için daha kaliteli ve eşit bir eğitim fırsatı sağlayabilmesi için dört alanda hazırlık yapılmasını önermektedir. Bunlar; Teknolojik hazırlık, içerik hazırlığı, pedagojik hazırlık ile izleme ve değerlendirme hazırlığıdır. İçerik hazırlığı, çevrimiçi platformlar, TV veya radyo programları aracılığıyla sunulabilen veya evde öğrenme için kullanılabilecek ulusal müfredatla uyumlu, basılı öğretme ve öğrenme materyallerine erişilebilirliği içermektedir (Can, 2020: 16). Açık ve uzaktan eğitim konusunda öne çıkan öğretmen eğitimi ihtiyacı, bilişim teknolojileri eğitimi, içerik geliştirme, tasarım ihtiyacı olarak görülmektedir. Örneğin yükseköğretimde açık öğretim fakültesi eski olmasına rağmen salgın sürecinde bazı eksiklikler ortaya çıkmıştır. Örneğin erişime açılan materyallerin tamamının basılı materyallerden oluşması, etkileşimli veya alternatif öğrenme kaynaklarına ihtiyaç olduğunu göstermiştir. Bu sayılar, ders içeriklerinin yeterli olmadığını göstermektedir. Bütün eğitim kademelerinde ders içeriklerine yönelik eksikliklerin öncelikli olarak giderilmesi gerekmektedir.

Covid 19 sonrası sanal/çevrimiçi eğitim artık bir tercih durumundan daha çok bir zorunluluk olacağı öngörülmektedir. Nitekim salgın süresince sanal sınıf olanağı sunan Google Classroom, Moodle, JoVE, Kahoot!, Pearson, Cisco Webex ClassMaster, Zoom, Adobe Connect, Age of Learning, Bloomz, CirQlive, Edhelper, G Suit for Education, Kiron gibi platformların kullanım oranları çok hızlı bir şekilde artmıştır. Bu platformlar dünyanın her yerinde aktif olarak bütün eğitim kademelerinde aktif olarak kullanılmaktadır (Arslan, 2020). Uluslararası raporlarda ise salgınının eğitime etkisiyle mücadelede iki konu öne çıkmaktadır (Özer, 2020):

- Sosyo-ekonomik seviyesi düşük öğrencilerin okullardaki çoğu ülkede günlük sağlıklı beslenme desteğini sadece okullarda alabildikleri için bu desteğin sürdürülebilmesi için ülkeler farklı uygulamalarda bulunmaktadır. Çevrimiçi kaynaklara erişim sıkıntısı çeken bu öğrencilere beslenme yanında eğitim materyal desteklerinin de dağıtılma olanakları konuşulmaktadır.

- Dijital platformda devam eden evde eğitim olanaklarındaki farklılıkların sebep olacağı sorunlar. Öğrenciler evde aynı çalışma ortamına sahip olmadığı gibi bilgisayar ve internet erişiminde de eşit haklara sahip değildir.

\section{SAPTAMALAR}

Korona virüs salgını, eğitimi derinden etkileyerek yeni duruma uygun şekillendirmektedir. Ancak yeniden şekillenen eğitim ortamları, materyalleri ve yöntemlerine sahip olma düzeyi herkes için eşit oranda gerçekleşmemektedir. Bütün dünya ülkeleri gibi ülkemizde de okullar arası mevcut başarı farkları sebebiyle uzaktan eğitimle öğrencilerin eğitimden kopmamaları için okulda hazır bulunuşluğun arttırılması hedeflenmektedir. Milli Eğitim Bakanlığı, uzaktan eğitim sürecinin öğrencilerin eğitime erişime yönelik farklarının giderilmesinde ve öğretim programlarının uygulamasında etkili olmuştur. Ancak Korona virüs salgın döneminde okulların salgın sonrasına iyi bir başlangıç yapmaları salgın sürecinde liderlik ve inisiyatif alabilme, hızlı ve etkili karar verebilme kapasitesine bağlıdır. Bu gibi olağanüstü durumlarda krizin eğitime yansımalarının boyutunu tam olarak göremeden ve kriz sonrasına yönelik sağlıklı bir kestirim olmadan erken karar almak, geleceğe dair yatırım tercihleri yapmak riskli olabilir. Eğitimde tüm paydaşların öğrencilerin sağlığını önemseyen kararlar alması beklenmektedir. Okullar yöneticiler, öğretmenler, veliler başta olmak üzere tüm tarafların kriz ortamını diğerlerinin aleyhine olacak şekilde faydaya dönüştürme yaklaşımlarından uzak durması gerekir. Okulların kapalı olduğu salgın sürecinde uzaktan eğitimde başarılı olmak için okul yöneticilerinin öğretmenlerle sürekli iletişim kurması gerekir.

Korona virüs sürecinde, öğretmen ve öğrenciler yeni dijital öğrenme yöntemleri ve teknolojik kaynaklarla desteklenmektedir. Bu yüzden teknolojinin sürekli öğrenmeyi kolaylaştırması eğitim sistemi içinde etkin öğretime yönelik daha yaygın olarak yer almalıdır. Korona virüs salgını tüm dünyaya alternatif eğitim olanaklarının oluşturulmasının önemini Türkiye'yi kapsayacak şekilde açık olarak göstermektedir.

Eğitim teknolojileri bağlamında eş zamanlı ve etkileşimli kaliteli eğitim olanağı sunulmalıdır. Bu salgın sayesinde tüm paydaşlar tarafından sanal eğitim olanakları kullanılması önemli bir fırsat alanı oluşturmaktadır. Ancak ülkemizde kullanılan uzaktan eğitim portalı Elektronik Bilişim Ağı (EBA) ile sanal eğitim platformu eğitimin kalitesinin artırılması, öğretmen ve öğrenciler için etkileşimli ortam oluşturulması amaçlanmış ancak dijital 
altyapı korona virüs salgını sonrası teknik olarak eğitimin çevrimiçi yapılmasını sağlayacak kapasiteye sahip olmadığı için aksaklıklar oluşmuştur. Okul yöneticileri ve öğretmenlerin çoğunun sanal/çevrimiçi eğitimde tecrübe ve donanımının olmaması da EBA'nın tüm eğitimde aktif olarak kullanılamamasının diğer önemli sebebi olarak kabul edilebilir (Altunel, 2020). Tüm dünyada olduğu gibi Türkiye'de de çevrimiçi eğitime geçişin bu kadar hızlı ve keskin olması sebebiyle bu eğitimi veren ve verecek olan eğitmenlerin önemli bir kısmının karşılaştığı bazı zorluklar ortaya çıkmıştır. Bilgisayar ve Öğretim Teknolojileri (BÖTE) öğretmenleri, salgın sonrası tüm okulların eğitim kadrolarının çevrimiçi eğitim konusunda eğitilmesi için önemli roller üstlenebilir (Telli Yamamoto ve Altun, 2020). Böylece uzaktan eğitimde eğitimcilerin bilgi ve beceri eksiklikleri giderilerek öğrencilerin olumsuzluk yaşama ihtimalleri giderilebilecektir.

\section{SONUÇ}

Çok yakın gelecekte sürekli öğrenme bağlamında uzaktan eğitimin yaşanan Korona virüs gibi zorunlu durumlar dışında da yüz yüze öğrenme kadar önemli bir eğitim platformu olacağı öngörülebilir. Ancak dijital öğrenmenin eğitimden beklenen kazanımlara hizmet etmesi için eğitim ortamlarının öğretmenlerle diğer okul paydaşlarının bu alanda gereken bilgi ve donanıma sahip olmaları gerekmektedir. Bunun için de bugünün öncelikli ihtiyacı olarak bir süre daha öğrencilerin evden/uzaktan eğitim alacaklarını bilerek dijital öğrenme ortamına uyumunu hızlandırmak ve yeni teknoloji sistemlerinin kullanımında başta okul yöneticileri, öğretmenler ve öğrenciler olmak üzere herkesin yeterliliğin arttırmak için gerekli önlemler alınmalıdır.

\section{KAYNAKÇA}

Akmansoy, V. (2012). Kaos Teorisi ve Eğitime Yansımaları. Mehmet Akif Ersoy Üniversitesi, Eğitim Bilimleri Enstitüsü, Burdur.

Akpınar, Y. (2003). Öğretmenlerin Yeni Bilgi Teknolojileri Kullanımında Yükseköğretimin Etkisi: İstanbul Okulları Örneği. The Turkish Online Journal of Educational Technology TOJET, 2(2).

Aktaş, U. (2020). Türkiye'de Salgının Eğitime Etkisi. https://sarkac.org/2020/05/turkiyede-salginin-egitime-etkisi-ogrenciler-dijital-ucurumu-anlatiyor/ Erişim tarihi: 22.08.2020.

Altıparmak, M., Kapıdere, M. ve Kurt, İ. D. (2011). E-Öğrenme ve Uzaktan Eğitimde Açık Kaynak Kodlu Öğrenme Yönetim Sistemleri. Akademik Bilişim'11-XIII. Akademik Bilişim Konferansı Bildirileri Kitabı (319-327). Malatya.

Altunel, M. (2020). 5 Soru: Koronavirüs (Covid-19) Salgınının Eğitim ve Öğretmenlere Etkisi. https://www.setav.org/5-soru-koronavirus-covid-19-salgininin-egitim-ve-ogretmenlere-etkisi/, Erişim tarihi: 20.04.2020.

Arkan, A. (2020, 22 Nisan). Koronavirüs sonrası eğitim. https:// www.setav.org/koronavirus-sonrasi-egitim/ Erişim tarihi: 22.08.2020.

Bozkurt, A. (2020). Koronavirüs (Covid-19) pandemi süreci ve pandemi sonrası dünyada eğitime yönelik değerlendirmeler: Yeni normal ve yeni eğitim paradigması. AUAd, 6(3). 112-142.

Burgess, S. ve Sievertsen, H. H. (2020). Schools, skills, and learning: The impact of COVID-19 on education. VOX CEPR Policy Portal. https://voxeu.org/article/impact-covid-19-education Erişim tarihi: 01.04.2020.

Bülbül, M. Ş. (2008). Kaos ve Eğitim. https://books.google.com. tr/books?id=0 mos0i1T0p8C \& printsec $=$ frontcover $\& h l=t r \&$ source $=g b s \_g e \_s u m m a r y \_r \& c a d=0 \# v=$ onepage

Can, E. (2020). Coronavirüs (Covid-19) pandemisi ve pedagojik yansımaları: Türkiye'de açık ve uzaktan eğitim uygulamalar. AUAd, 6(2), 11-53.

Cantekin, B. (2020). Corona Virüs Online Eğitimi Nasıl Etkiledi? https://www.iienstitu.com/blog/corona-virus-online-egitimi-nasil-etkiledi Erişim tarihi: 16.09.2020.

Cao, H, J. Jiang, L. B. Oh, Li, H. X. Liao, ve Z. Chen (2013). A Maslow's hierarchy of needs analysis of social networking services continuance. Journal of Service Management, 24(2), 170-190.

Çetinkaya Aydın, G. (2020). COVID-19 Salgını Sürecinde Öğretmenler. https://tedmem.org/covid-19/covid-19-salgini-surecinde-ogretmenler adresinden erişim tarihi: 25.10.2020.

Ergüney, M. (2015). Uzaktan eğitimin geleceği: MOOC (Massıve open onlıne course). Eğitim ve Öğretim Araştırmaları Dergisi (Journal of Research in Education and Teaching), 4 (4), 15-22.

Erktin, E. (2020). https://haberler.boun.edu.tr/tr/haber/ prof-dr-emine-erktin-salginda-uzaktan-egitim-konusulurken-egitimde-nitelik-ve-icerik-goz-ardi Erişim tarihi: Öndeş, Ö. 25.05.2020.

Ersoy, F. (2018). Ilham Veren Sosyal Bilgiler Öğretmenlerinin Ahlaki Kimlik Profillerinin Gömülü Teori Bağlamında Incelenmesi. Marmara Üniversitesi, Eğitim Bilimleri Enstitüsü, İstanbul.

Göral, F. (2020). https://fef.istinye.edu.tr/tr/haberler/pandemi-doneminde-hayat-boyu-ogrenmenin-onemi. Erişim tarihi: 25.08 .2020 .

Gündüz Öğüdücü, Ş. (2020). Koronavirüs sonrası eğitim düzeni. https://bilimgenc.tubitak.gov.tr/makale/koronavirus-sonrasi-yeni-egitim-duzeni Erişim tarihi: 01.09.2020.

Işık, M. ve Çetin, M. (2019). Farklı Kariyer Evrelerindeki Okul Yöneticilerinin Profesyonel Öğrenme Düzeyleri, Kastamonu Eğitim Dergisi, 27(2), 824-836.

Kahraman, M. E. (2020). COVID-19 Salgınının Uygulamalı Derslere Etkisi ve Bu Derslerin Uzaktan Eğitimle Yürütülmesi: Temel Tasarım Dersi Örneği, Medeniyet Sanat-iMÜ Sanat Tasarım ve Mimarlık Fakültesi Dergisi, 6(1), 44-56. https:// doi.org/10.46641/medeniyetsanat.741737

Karip, E. (2020). Covid 19 Okulların kapatılması ve sonrası. https://tedmem.org/vurus/covid-19-okullarin-kapatilmasi-ve-sonrasi Erişim tarihi: 24.08.2020.

Keleş, M. (2020). Uzaktan Eğitim Platformlarının Avantajları ve Dezavantajları. https://binbiriz.com/blog/uzaktan-egitim-platformlarinin-avantajlari-ve-dezavantajlari Erişim tarihi: 23.08.2020.

Kırık, A. M. (2014). Uzaktan Eğitimin Tarihsel Gelişimi ve Türkiye'deki durumu. Marmara Iletişim Dergisi / Marmara Uni- 
versity Journal of Communication, 21(73-94).

Kırmızı̈ül, H. G. (2020). Covid-19 Salgını ve Beraberinde Getirdiği Eğitim Süreci, Avrasya Sosyal ve Ekonomi Araştırmaları Dergisi (ASEAD), 7(5), 283-289.

Leh, A. S. C. (1998) Design of a computer literacy course in teacher education. Technology and Teacher Education Annual, Online. AACE. ttp://www.coe.uh.edu/insite/elec_pub/ html1998/toc2.htm

Mocu, E. N. (2020). https://www.sigortacigazetesi.com.tr/salgin-ile-beraber-yasanan-zorunlu-dijitallesme-ogretmenlerin-rolunu-degistirecek-mi/ Erişim tarihi: 25.08.2020.

Moore, M. G. (1973). Towards a theory of independent learning and teaching. Journal of Higher Education, 44(9), 661-679.

OECD (2020, Ağustos 29). Efforts to contain virus and save lives should be intensified, and governments should plan stronger, more co-ordinated measures to absorb growing economic blow. https://www.oecd.org/coronavirus/en/ adresinden erişim sağlanmıştır.

Özer, M. (2020, Mayıs 18). Covid Salgını Sonrası Dünyada Eğitim. http://www.meb.gov.tr/covid-19-salgini-sonrasi-dunyada-egitim/haber/20936/tr Erişim tarihi: 23.08.2020.

Özer, M. ve Suna, H. E. (2020). Covid-19 salgını ve eğitim. M. Şeker, A. Özer ve C. Korkut, (Ed.), Küresel toplumun anatomisi: Insan ve toplumun geleceği içinde (171-192). Ankara: Türkiye Bilimler Akademisi - TÜBA.

Özgenel, M., Işık, M. ve Bahat, İ. (2019). Öğretmenlik İmajı: Bir Ölçek Geliştirme Çalışması, Ankara Üniversitesi Eğitim Bilimleri Fakültesi Dergisi, 52(3). 871-892 DOI: 10.30964/auebfd.461440, E-ISSN: 2458-8342, P-ISSN: 1301-3718.

Pina, A. A. (2008). How institutionalized is distance learning? A study of institutional role, locale and academic level. Online Journal of Distance Learning Administration, 11(1). http://www.westga.edu/ distance/ojdla/spring111/ pina111.html Erişim tarihi: 21.06.2015.

Shisley, S. (2020). Emergency remote learning compared to online learning. Erişim Tarihi: 31.10.2020.https://shorturl.at/ gosyC

Simonson, M. (2007). Institutional policy issues for Distance Education. In M. G. Moore, (Eds.), Handbook of Distance Education. (pp 355-363) Mahwah, N.J. Lawrence Erlbaum Associates.

The World Bank Report Education (May, 2020). The COVID-19 Pandemic: Shocks to education and policy responses. Retrieved from https://openknowledge.worldbank.org/bitstream/handle $\quad / 10986 / 33696 / 148198 . p d f$ sequence $=4 \& i-$ sAllowed $=y$.

Tekke, M. (2019). Maslow'un ihtiyaçlar hiyerarşisinin en son düzeyleri: Kendini gerçekleştirme ve kendini aşmışlık. Eğitimde Nitel Araştırmalar Dergisi, 7(4), 1704-1712. doi: 10.14689/issn.2148-2624.1.7c.4s.17m

Telli Yamamoto, G. ve Altun, D. (2020). Coronavirüs ve Çevrimiçi (Online) Eğitimin Önlenemeyen Yükselişi, Üniversite Araştırmaları Dergisi, 3(1), 25-34.

Telli Yamamoto, G., Demiray, U. ve Kesim, M. (2011). Türkiye'de e-öğrenme: Gelişmeler ve Uygulamalar. Elif Yayınevi.

Telli Yamamato, G. (2012). Fatih Projesi Geleceğin Eğitimi Çalıştayı, Okan Üniversitesi, İstanbul.

Telli Yamamoto, G. ve Can, E. (2013). Türkiye'de Uzaktan Eği- tim Uygulamalarının Analizi. Yüzer, T. V., Telli Yamamato, G. ve Demiray, U. (Ed.). Türkiye'de e-Öğrenme: Gelişmeler ve Uygulamalar IV içinde (s. 193-206). Anadolu Üniversitesi Yayınları, No: 3016, Eskişehir.

Şişman, M. (2010). Eğitim bilimlerine giriş. Ankara: Pegem Yayınları.

UNESCO. (2020). COVID-19 educational disruption and response. https://en.unesco.org/covid19/educationresponse Erişim tarihi: 25.10.2020.

https://tr.wikipedia.org/wiki/Uzaktan_e\%C4\%9Fitim. Erişim tarihi: 21.08.2020. 